\title{
DOUBTFUL SUSTAINABILITY OF PUBLIC FINANCES IN SLOVENIA
}

\author{
Primož Dolenc*
}

\begin{abstract}
:
In the immediate period before adoption of euro many debates in Slovenia deal with fulfillment of Maastricht criteria. Slovenia has never had any significant problems with Maastricht fiscal criteria, but this does not mean that it has long-term sustainable fiscal situation. The purpose of this analysis is analyze (non)sustainability of Slovenia's fiscal stance. The methodology is based on objective analysis of long-term public finance's stability/sustainability. The analysis shows that Slovenia exceeded several times the level of sustainability in previous years. In next period the circumstances could only worsen unless necessary fiscal reform and other policy measures (especially reform of public-debt management) are introduced.
\end{abstract}

Keywords: public finance, sustainability, budget, deficit, debt

JEL Classification: H2O, H62, H63

\section{Introduction}

In recent years, as Slovenia has been rapidly approaching European and other international integrations, the question of (non)sustainability of its public finances is becoming more and more topical. One of broader and publicly accepted goals is early adoption of euro; the project is to be realized in early 2007. Famous Maastricht criteria are well known and accepted in Slovenia. The last obstacle before acceptance of euro was a slightly higher inflation rate, which properly converged in the beginning 2006.

It is broadly accepted that Maastricht fiscal criterium is connected with longterm public finance's sustainability and that countries, fulfilling these criteria, cannot get into public finances difficulties: their public finances are therefore "healthy". However, many studies ${ }^{1)}$ show that the two Maastricht fiscal criteria were political-

\footnotetext{
*) Assistant professor, University of Primorska, Faculty for Management Koper (primoz.dolenc@fm-kp.si).

1) For example Pasinetti (1998), Papadopoulos and Sidiropoulos (1999), Fatás and Mihov (2003), Eichengreen and Wyplosz (1998) and others.
} 
ly motivated. With adoption of single European currency the country already loses its monetary policy, therefore is it unreasonable or economically unacceptable to limit also its fiscal policy. These debates mostly started soon after the acceptance of the criteria and stopped immediately after most of EU Member States successfully adopted euro in 1999. It is the fact that most of (also academic) critics of Maastricht criteria originated from countries, where public debt and budget deficit was significantly higher than a defined limit (this was mostly the case for Italy and Belgium). The idea is again interesting because new EU Member States are eager to prepare their economy for imminent adoption of euro.

This paper tackles three main questions:

1. what are objective preconditions of public finance's sustainability,

2. where Slovenia stands in this respect and

3. what is (long-term) fiscal situation in Slovenia.

The analysis shows that public finance's sustainability in Slovenia has to be viewed through broader perspective and not only through a narrow perspective fulfillment of Maastricht fiscal criteria. These criteria are fulfilled in Slovenia, but it still does not assure long-term public finance's sustainability in Slovenia. According to our analysis Slovenia is currently on or even under the limit of long-term sustainability of public finances, but in near future the situation would be very likely even worse - ceteris paribus. Therefore quick public finance's reform is necessary, even though public finance's sustainability can be somehow supported with promotion of economic growth and lowering cost of public debt.

The rest of the paper is organized as follows. The second chapter tackles the question of the criteria of public finance's sustainability; here we show one view on that puzzle, discuss the "myth" of Maastricht fiscal criteria and analyze where Slovenia stands in this respect. In the third chapter - before conclusion and some policy recommendations - (long-term) fiscal situation in Slovenia is analyzed.

\section{What is the Sustainability of Public Finances (of Public Debt)?}

Studies of public finance sustainability are usually based on searching of optimal level of public debt. Economic theory finds the public finance sustainability in the level of budget deficit that does not change (significantly) the ratio between public debt and budget incomes (Easterly et al, 1995). According to Collignon and Mundschenk (1999) such a definition relates not only to solvency of public finances (i.e. the capability of the country to service their public debt obligations) but primarily on its willingness to fulfill these obligations. If a country allows a stable growth of public debt, it can get into the so-called Ponzi trap, which can at the end cause the inability to service its public debt obligations. Nevertheless, it is still better for a country to finance its budget deficit with borrowing instead of inflationary (with money printing) (McCallum, 1984). McCallum in his analysis has not explicitly suggested what the optimal level of public debt is, but has proved, that long-term sustainable growth of public debt-to-GDP ratio should not exceed the average level of (nominal) interest rate, paid on public debt. 


\subsection{Optimal Level of Public Debt According to Blanchard}

Several researchers ${ }^{2)}$ have tried to determine the optimal level of public debt with one of the basic macroeconomic identities - the so called (dynamic) budget constraint of the country:

$$
\frac{d B}{d s}=G+H-T+i \cdot B
$$

where:

$-\frac{d B}{d s}-$ increase $(+)$ or decrease $(-)$ of public debt,

- $G$ - budget consumption (without interest payments on public debt),

$-H-$ transfer payments,

$-T$ - collected taxes and

$-i B-$ interests payments on public debt.

Blanchard et.al. have methodologically best solved the problem of optimal level of public debt (in the framework of the analysis of public finance sustainability). Their reference text is the debate on public finance sustainability as "a new answer to an old question" (Blanchard et al, 1990). They believe the question of public finance sustainability is mostly the question whether a country long-term trend of public debt accumulation goes over limit; the best indicator is therefore already mentioned public debt-to-GDP ratio.

They begin their arguments with basic identity [1], where they define first three elements as primary budget deficit. Turning to relative terms they get the following equation:

$$
\frac{d b}{d s}=g+h-t+(r-\theta) \cdot b=d+(r-\theta) \cdot b
$$

where:

$-\frac{d b}{d s}-$ increase $(+)$ or decrease (-) of public debt-to-GDP ratio,

- $g$ - government spending-to-GDP ratio (without interests payments on public debt),

$-h-$ transfer payments-to-GDP ratio,

$-t-$ collected taxes-to-GDP ratio,

$-d-$ primary deficit-to-GDP ratio,

$-\theta-$ real growth of GDP and

$-r-($ ex post $)$ real interest rate ${ }^{3)}$.

Public debt-to-GDP ratio is a function of two factors. The first is primary deficit; it shows current budget spending, transfer payments and tax policy. The other factor - product of accumulated public debt (relative to GDP) and the difference

2) For example Blanchard et al (1990), Papadopolous and Sidiropoulos (1999), Herring (1995), De Haan and Sierman (1993), Heinemann (1993), Mac Donald and Speight (1990), Uctum and Wickens (1997) and others.

3) This is nominal interest rate, calculated to real terms by Fisher's theorem. 
between real interest rate and growth of GDP - shows past evolution of public finances. If real interest rate exceeds the growth of GDP, a country needs primary surplus to keep the level of public debt-to-GDP ratio constant.

Authors explain the fiscal policy as a complex of rules (on public spending, transfer payments, taxes, etc.) and inherited public debt (relative to GDP). Sustainable fiscal policy is considered as policy, which enables the public debt-to-GDP ratio to converge into its initial level.

In order to have a sustainable fiscal policy a country with existing/initial public debt has to reach budget surplus sooner or later. The later should be high enough and has to fulfill the following condition:

$$
\int_{0}^{\infty} d_{s} \exp -(r-\theta) \cdot s \cdot d s=-b_{0}
$$

where:

$-b_{0}-$ initial public debt-to-GDP ratio.

The implicit assumption is that real interest rate on public debt is higher that growth of GDP. On the other hand, if real interest rate on public debt is lower that growth of GDP, the conclusion is somehow different and a bit less limited for fiscal policy: in this case the public debt-to-GDP ratio would be falling with a rate of $(r-\theta)$ in a country with budget surplus. However, also with budget deficit a country could easily has constant (but positive) level of public debt (relative to GDP).

The later case is more or less theoretical, because on long-run real interest rate, lower than economic growth, is not sustainable. This fact has been empirically proven by Papadopoulos and Sidiropoulus (1999) in their discussion of public finance's sustainability in EU Member States.

As strange as it may seem Blanchard et al (1990) did not solve the question of optimal level of public debt (relative to GDP). They only showed what a fiscal policy should be (in connection to public debt) in order to be sustainable in the long run. They explicitly state that a country with a stable, 40 per cent public debt-toGDP ratio is no less sustainable than a country with a stable, 20 per cent public debtto-GDP ratio (on condition that they all have similar other characteristics). A country should only lead a fiscal policy that keeps the public debt-to-GDP ratio stable in the long run.

\subsection{The Myth of Maastricht Fiscal Criteria}

The appropriate level of public debt became (again) very topical with acceptance of the so called Maastricht Treaty, which in its $103^{\text {rd }}$ article anticipates the coordination of macroeconomic policies (Commission of European Communities, 1992). The article 109j of this Treaty is about criteria a country has to fulfill in order to be able to adopt euro. Among those probably the most critics were on criteria of sustainable public finances. Two conditions are crucial: a) public debt-to-GDP ratio should not exceed 60 per cent and $b$ ) budget deficit should not exceed 3 per cent of GDP. Later on the criteria for public debt-to-GDP ratio has been loosened; now it is enough for this ratio to be in the long-term trend converging to reference value.

One of the most profound critiques of Maastricht (fiscal) criteria is Pasinetti's critique in his argument on "the Myth (or Folly) of Maastricht Criteria" (Pasinetti, 
1998). The core of his critique is that Maastricht Treaty does not either mention the concept of public finance's sustainability nor it defines the relation between public debt-to-GDP ratio (as one limit or criteria) and budget deficit-to-GDP ratio (as the other limit or criteria). In his analysis he showed that the two defined references are only two (of infinite) points in the area of public finance's sustainability.

According to Pasinetti the limit of 60 per cent for public debt-to-GDP ratio originates from average figures of EU Member States in years when the Treaty was being adopted. At the time Germany and France were on the limit, but Italy and Belgium stepped out significantly. Because public debt cannot be (without significant macroeconomic consequences) lowered relatively fast, the crucial is article $104 \mathrm{c}$, which later reduced this limit to the long-term trend to reference value.

Pasinetti bases his analysis on already mentioned Blancard's definition of optimal level of public debt (Blanchard et al, 1990), but with only one year's time horizon. Similar as Blancard Pasinetti also considers the level of public debt-to-GDP ratio as exogenous, because - as he argues - it is "theoretically impossible to set the optimal level of public debt-to-GDP ratio". Therefore public debt-to-GDP ratio is not crucial; what is crucial is its dynamics. Pasinetti defines the sustainability of public debt $\mathrm{as}^{4)}$ :

$$
\left(\frac{B}{Y}\right)_{(s)} \leq\left(\frac{B}{Y}\right)_{(0)}
$$

where:

$-B>0$ - public debt,

$-Y-$ nominal one year's GDP and

$-s-$ time (years).

Public debt is sustainable if it has a falling trend or at least constant. Therefore the following should hold:

$$
\frac{\frac{d b}{d s}}{\theta_{n}} \cdot \frac{B}{Y} \leq \frac{B}{Y} \Rightarrow \frac{d b}{d s} \leq \theta_{n},
$$

where:

$-\frac{d b}{d s}-$ increase $(+)$ or decrease $(-)$ of public debt-to-GDP ratio and

$-\theta_{n}-$ yearly nominal growth of GDP.

He included total and primary budget deficit and nominal interest rate on public debt and so defined the two conditions of public finance's sustainability a little differently ${ }^{5)}$ than Blanchard et al (1990). The two conditions are as follows:

$$
\frac{S}{Y} \geq-\theta_{n} \cdot \frac{B}{Y} \text { and }
$$

4) Symbols have the same meaning as above.

5) He focused primarily on connection between public debt-to-GDP ratio and budget deficit-toGDP ratio. 


$$
\frac{S_{p}}{Y} \geq\left(i-\theta_{n}\right) \cdot \frac{B}{Y},
$$

where:

$-S=-d B-$ total (yearly) budget surplus or deficit (this defines the change of public debt in one year),

$-S_{p}-$ (yearly) primary budget surplus and

$-i-$ (yearly) nominal interest rate on public debt.

Public finance's sustainability can therefore be defined with a connection to:

a) total budget surplus or deficit ([6] and Figure 1) or

b) primary budget surplus or deficit ([7] and Figure 2).

Figure 1

Public Finance's Sustainability with a Connection to Total Budgetary Surplus or Deficit

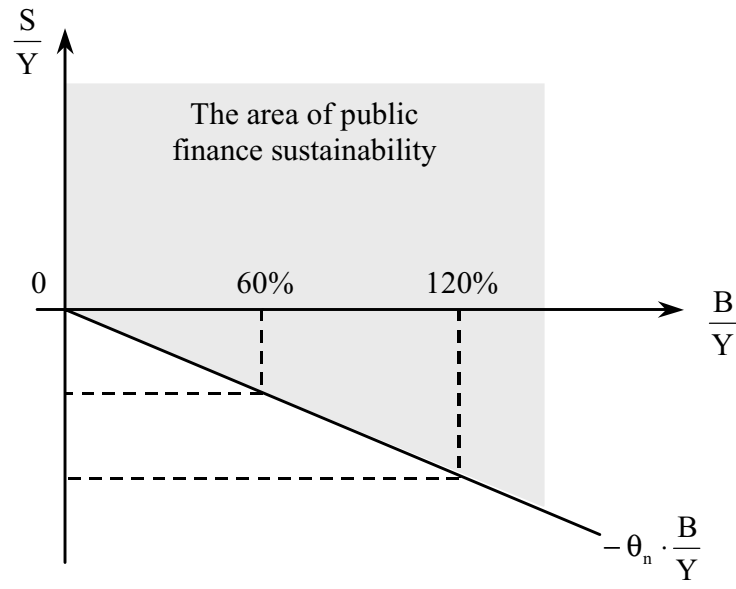

Figure 2

Public Finance's Sustainability with a Connection to Primary Budget Surplus or Deficit

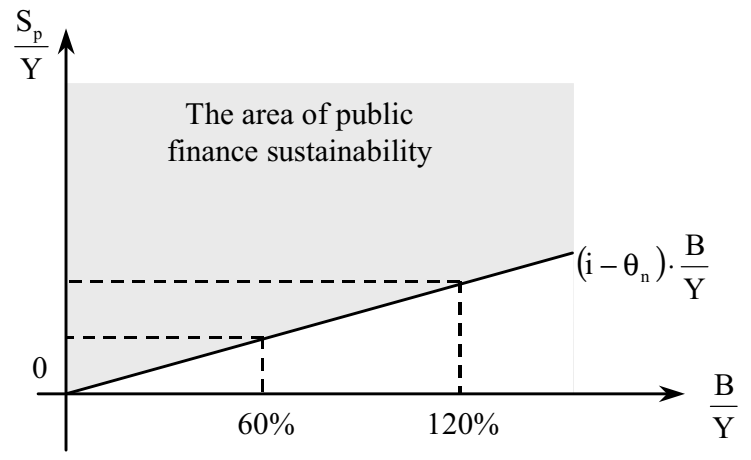


The example a) connects total budget surplus or deficit with growth of GDP and public debt-to-GDP ratio. This is the basis for the determination of Maastricht Treaty's 3 per cent limit for total budget deficit-to-GDP ratio. A country with 60 per cent public debt-to-GDP ratio and 5 per cent growth of GDP should not exceed 3 per cent total budget deficit. Maastricht fiscal criteria are therefore only one of infinite points (combinations) in the area of public finances sustainability.

The example b), which is bound to primary budget surplus or deficit, incorporates more information. In fact three external factors: public debt-to-GDP ratio, interest rate on public debt and growth of GDP. If, for example, the interest rate on public debt exceeds the growth of GDP for more than 2 percentage points and if public debt-to-GDP ratio is 60 per cent, the primary surplus-to-GDP ratio should be 1.2 per cent. Or expressed alternatively: if a country has 60 per cent public debtto-GDP ratio and the interest rate on public debt exceeds the growth of GDP for more than 2 percentage points, it has to have 1.2 per cent primary budget surplus in order to have stable public debt and sustainable public finances. With the same difference between interest rate on public debt and growth of GDP the sustainable primary budget surplus should be twice as high if public debt-to-GDP ratio is 120 per cent. One can recollect again a theoretical possibility when interest rate on public debt is lower than growth of GDP; in this case a country could have stable public debt-to-GDP ratio and sustainable fiscal policy even with primary budget deficit (instead of surplus).

The core of Pasinetti's analysis is therefore the following: public debt-to-GDP ratio and budget deficit-to-GDP ratio are connected with well defined relation. At a given economic growth higher public debt-to-GDP ratio corresponds to higher total budget deficit-to-GDP ratio. At the same time a country should have - in order to stay in the area of fiscal policy sustainability and if a nominal interest rate on public debt exceeds economic growth - higher primary budget surplus if it has higher public debt-to-GDP ratio.

\subsection{Where Does Slovenia Stand according to Trends in Public Finances}

Regardless the above arguments the two reference values of Maastricht fiscal criteria still stay the most important for Slovenia in the current period. They are official limits, which should not be exceeded and in fact have not been exceeded yet. The public debt-to-GDP ratio is currently less than half of the determined and budget deficit stays below the reference value, although budget surplus turned to budget deficit in mid 1990s. The only obvious problem is perhaps continuous growth of public debt.

Nevertheless, we wanted to place Slovenia in the circle of "old" EU Member States (i.e. EU15). With this we wanted to find in what position is Slovenia compared to these countries regarding their macro-fiscal developments in recent years.

We performed the analysis covering the period from 1993 to 2004. The analysis was performed in two stages. First we estimated with OLS regression the initial value of the selected variable ${ }^{6)}$ (regression constant) and average (absolute) growth

6) We selected three variables: total and primary budget deficit (surplus), and public debt (all variables were calculated against GDP). 
of the variable in the whole period (regression coefficient). These parameters were then used in cluster analysis, which was performed twice:

1. first we performed hierarchical clustering with Ward's method, which was used to determine the appropriate number of groups and the calculation of groups' centroids, and

2. non-hierarchical clustering with K-means method.

EU15 Member States can be clustered in three groups (Figure 3):

1. group: Italy, Belgium, Denmark, the Netherlands and Ireland;

2. group: Sweden, Finland and Greece; and

3. group: the United Kingdom, Spain, France, Austria, Portugal, Germany and Luxembourg.

Figure 3

The Results (dendrogram) of Clustering the EU15 Member States according to Public Debt, and Total and Primary Deficit or Surplus in 1993 to 2004

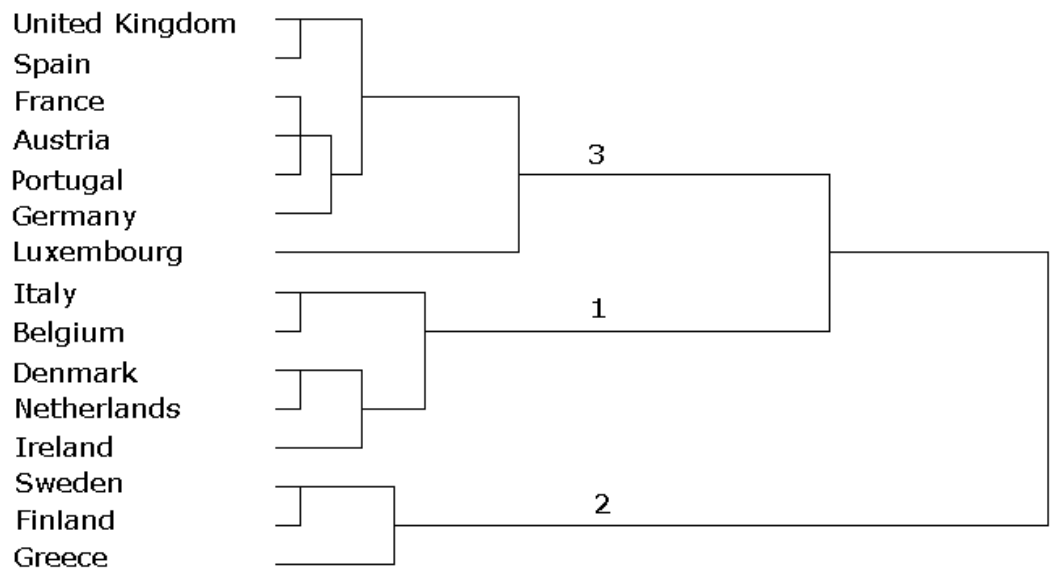

*) All variables were calculated against GDP.

Source: ECB (2004), OECD (2003) own calculations.

Table 1 shows basic characteristics of all three groups of EU15 Member States, clustered with described method. With respect to fulfillment of Maastricht fiscal criteria the least problematic were members of the third group. These countries had their public debt relatively stable and mostly under the limit. Besides that they had initial budget surplus, which mostly converged to 0 until 2004.

Sweden, Finland and Greece (the second group of countries) have all had relatively high total and primary budget deficits in early years, but they were able to lower them fairly fast. Finland did not have its budget deficit over the limit (such as Sweden and Greece), but all three countries intensively lowered their public debt (relative to GDP) in recent years (on average 2 percentage points yearly).

The common characteristics for the first group of countries is that they all had relatively high public debt and costs of servicing this debt. The later fact resulted in relatively sustainable total budget deficit, but high primary budget deficit. Pro- 
bably under the pressure of Maastricht fiscal criteria all these countries decreased their public debt significantly before the adoption of euro; average yearly decrease accounted almost 4 percentage points. Denmark, the Netherlands and Ireland reached the reference value for public debt before 1999, Italy and Belgium still have not reached the 60 per cent limit (probably due to enormous initial public debt).

Table 1

Characteristics (estimated initial value and average growth) of All Three Groups of Countries with Respect to Total and Primary Budget Deficit or Surplus, and Public Debt in 1993 to 2004

\begin{tabular}{|l|c|c|c|c|c|c|}
\hline & $\begin{array}{c}\text { Initial total } \\
\text { budget defi- } \\
\text { cit/surplus }\end{array}$ & $\begin{array}{c}\text { Average } \\
\text { growth of } \\
\text { budget defi- } \\
\text { cit/surplus }\end{array}$ & $\begin{array}{c}\text { Initial pri- } \\
\text { mary budget } \\
\text { deficit/surplus }\end{array}$ & $\begin{array}{c}\text { Average } \\
\text { growth of } \\
\text { primary } \\
\text { budget de- } \\
\text { ficit/surplus }\end{array}$ & $\begin{array}{c}\text { Initial } \\
\text { public } \\
\text { debt }\end{array}$ & $\begin{array}{c}\text { Average growth } \\
\text { of public debt }\end{array}$ \\
\hline Group 1 & $-3,339$ & 0,452 & 3,154 & 0,019 & 103,590 & $-3,701$ \\
\hline Group 2 & $-8,344$ & 1,161 & $-4,896$ & 0,933 & 84,029 & $-2,199$ \\
\hline Group 3 & $-4,097$ & 0,355 & $-0,715$ & 0,228 & 50,160 & 0,008 \\
\hline Total & $-4,693$ & 0,549 & $-0,262$ & 0,299 & 74,744 & $-1,670$ \\
\hline
\end{tabular}

*) and EU15 as a whole

**) All variables were calculated against GDP.

Source: ECB (2004), OECD (2003) and own calculations.

Method of non-hierarchical clustering placed Slovenia in the third group of countries. Slovenia can therefore be considered as a non-problematic country considering Maastricht fiscal criteria. Slovenia is most similar to Luxembourg - square Euclidean distance between these two countries is even smaller than between France and Germany.

With respect to Maastricht fiscal criteria Slovenia did not or should not have problems; so one could argue that public finance situation in Slovenia is highly sustainable. However, the fulfillment of arbitrary criteria is less important; more important is de facto sustainability of public finances in Slovenia. This is the question will be tackled in next section.

\section{What Is (longer-term) Public Finance Situation in Slovenia?}

The analysis of long-term public finance sustainability was based on the above mentioned arguments and analysis of Pasinetti (1998). For 10 years period (from 1995 to 2004) we calculated parameters of equations [6] and [7] and with this respect we estimated, whether public finance situation in Slovenia is in the long run sustainable or not (Table 2 and 3, and Figure 4 and 5).

Table 2 shows that until 2004 Slovenia has not yet exceeded the limit of maximal stabilization budget deficit (relative to GDP). The later has been - because of high (nominal) growth in the analyzed period - on average 2.9 per cent; at the same 
time the actual budget deficit (relative to GDP) accounted the average of less than 1 per cent. However, the dynamics of both categories, shown in Figure 4, clearly shows, that the spread between the two categories is constantly decreasing. With a simple analysis of trend one could forecast that the spread will reach 0 or even negative value already in 2005. After 2005 the actual budget deficit could become ceteris paribus - too high with respect to public debt-to-GDP ratio and economic growth.

Table 2

Data on Economic Growth and Public Debt-to-GDP and Budget Deficit-to-GDP Ratio for Slovenia in 1993 to 2004

\begin{tabular}{|c|r|r|r|r|r|}
\hline Year & \multicolumn{1}{c|}{$\frac{B}{Y}$} & \multicolumn{1}{c|}{$\theta_{\mathrm{n}}$} & $\frac{S}{Y}$ & \multicolumn{1}{c|}{$-\theta_{n} \cdot \frac{B}{Y}$} & \multicolumn{1}{c|}{$\begin{array}{c}\text { Difference } \\
\text { (3) - (4) }\end{array}$} \\
& \multicolumn{1}{c|}{$(1)$} & \multicolumn{1}{c}{$(2)$} & \multicolumn{1}{c}{$(3)$} & \multicolumn{1}{c}{$(4)$} & \multicolumn{1}{c|}{$(5)$} \\
\hline 1995 & 17,5 & 28,9 & 0,8 & $-5,1$ & 5,9 \\
\hline 1996 & 21,3 & 14,1 & 0,7 & $-3,0$ & 3,7 \\
\hline 1997 & 21,7 & 13,8 & $-1,0$ & $-3,0$ & 2,0 \\
\hline 1998 & 22,3 & 11,5 & $-1,0$ & $-2,6$ & 1,5 \\
\hline 1999 & 23,1 & 11,8 & $-0,5$ & $-2,7$ & 2,2 \\
\hline 2000 & 23,8 & 10,0 & $-0,9$ & $-2,4$ & 1,5 \\
\hline 2001 & 25,8 & 12,0 & $-1,0$ & $-3,1$ & 2,1 \\
\hline 2002 & 26,7 & 11,6 & $-2,6$ & $-3,1$ & 0,5 \\
\hline 2003 & 25,9 & 8,1 & $-1,2$ & $-2,1$ & 0,9 \\
\hline 2004 & 26,4 & 7,7 & $-1,3$ & $-2,0$ & 0,7 \\
\hline
\end{tabular}

Legend:

$-\frac{B}{Y}-$ public debt-to-GDP ratio,

$-\theta_{n}-$ yearly nominal growth of GDP,

$-\frac{S}{Y}-$ actual budget surplus (+) or deficit (-), relative to GDP, and

$-\theta_{n} \cdot \frac{B}{Y}$ - maximal stabilization budget surplus (+) or deficit (-), relative to GDP.

Source: UMAR (1996), UMAR (2005), MF (2005), and own calculations and estimates. 
Figure 4

Dynamics of Economic Growth and Public Debt-to-GDP and Budget Deficit-to-GDP Ratio for Slovenia in 1993 to 2004

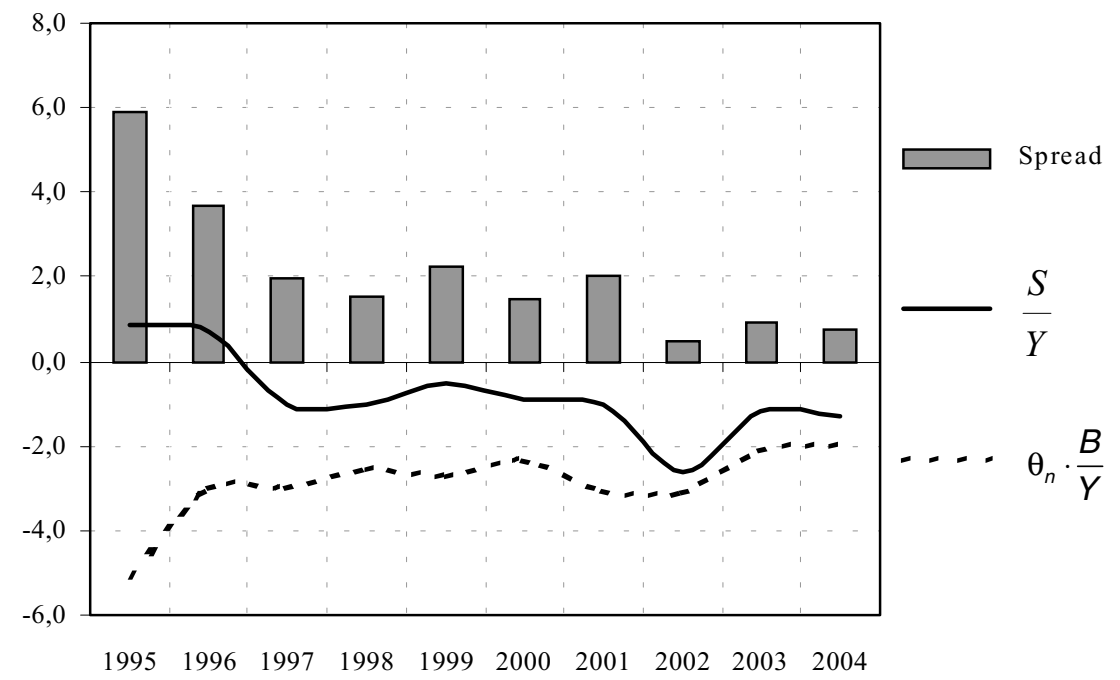

Source: Table 2.

Similar, but somehow more dramatic is the situation when comparing actual primary budget surplus/deficit, relative to GDP, with the adequate limit for long-term public finance sustainability. Since 1997 Slovenia was mostly under the limit (Table 3 and Figure 5). In addition the dynamics in recent years indicates the relatively unfavorable trends in next future. Negative spread has been constantly increasing and can in near future - ceteris paribus - reach an unacceptable 3 percentage points! 
Table 3

Data on Economic Growth and Public Debt-to-GDP and Primary Budget Deficit-toGDP Ratio for Slovenia in 1993 to 2004

\begin{tabular}{|c|r|r|r|r|r|}
\hline Year & \multicolumn{1}{|c|}{$i$} & $\left(i-\theta_{n}\right)$ & $\frac{S_{p}}{Y}$ & $\left(i-\theta_{n}\right) \cdot \frac{B}{Y}$ & $\begin{array}{c}\text { Difference } \\
(3)-(4)\end{array}$ \\
& \multicolumn{1}{c|}{$(1)$} & $(2)$ & $(3)$ & \multicolumn{1}{c|}{$(4)$} & \multicolumn{1}{c|}{$(5)$} \\
\hline 1995 & 32,2 & 3,3 & 1,8 & 0,6 & 1,2 \\
\hline 1996 & 10,4 & $-3,7$ & 1,8 & $-0,8$ & 2,5 \\
\hline 1997 & 17,4 & 3,6 & 0,0 & 0,8 & $-0,8$ \\
\hline 1998 & 11,0 & $-0,4$ & 0,1 & $-0,1$ & 0,2 \\
\hline 1999 & 16,7 & 4,9 & 0,7 & 1,1 & $-0,4$ \\
\hline 2000 & 16,1 & 6,1 & 0,4 & 1,5 & $-1,1$ \\
\hline 2001 & 11,4 & $-0,6$ & 0,3 & $-0,1$ & 0,5 \\
\hline 2002 & 11,2 & $-0,4$ & $-1,2$ & $-0,1$ & $-1,1$ \\
\hline 2003 & 9,0 & 0,9 & 0,2 & 0,2 & $-0,1$ \\
\hline 2004 & 9,9 & 2,1 & 0,0 & 0,6 & $-0,6$ \\
\hline
\end{tabular}

Legend:

$-i-$ yearly nominal interest rate on public $\mathrm{debt}^{7}$,

$-\frac{S_{p}}{Y}-$ actual primary budget surplus (+) or deficit (-), relative to GDP, and,

- $\left(i-\theta_{n}\right) \cdot \frac{B}{Y}-$ maximal stabilization primary budget surplus $(+)$ or deficit (-), relative to GDP.

Source: UMAR (1996), UMAR (2005), MF (2005), and own calculations and estimates.

7) Because of very complex portfolio of public debt it is impossible to calculate the actual interest rate on public debt. I estimated it as quotient between paid interests on public debt and the amount of public debt at the end of previous year. 
Figure 5

Data on Economic Growth and Public Debt-to-GDP and Primary Budget Deficit-toGDP Ratio for Slovenia in 1993 to 2004

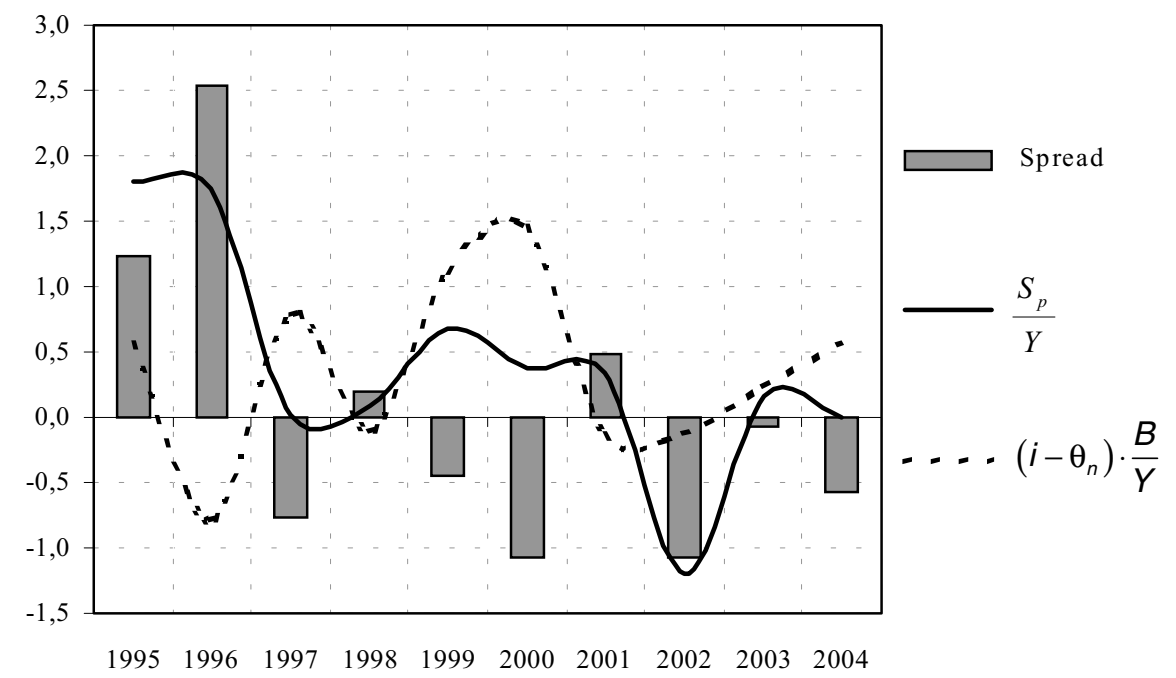

Source: Table 3.

\section{Conclusion}

The purpose of this analysis was to find theoretical background and empirical facts about public finance (non)sustainability in Slovenia. Theoretical background states that sustainability of public finances has to be viewed not only through the perspective of Maastricht criteria, but broader. Slovenia does not have any problems fulfilling Maastricht criteria; this is - however - not the guarantee for the long-term sustainability of its public finances. Analysis of the long-term public finance sustainability shows that Slovenia is currently on or already under the limit, but in near future the situation will - ceteris paribus - get only worse.

The maximal stabilization budget deficit, relative to GDP, has been relatively high in Slovenia. This has been due to relatively high (nominal) economic growth in the analyzed period. The limit has been decreasing in the last few years, mostly because economic growth has weakened. At the same time the actual budget deficit-to-GDP ratio has been increasing. As a result the spread between the limit and actual figures has been lowering and has been approaching to negative value. The comparison between actual and maximal primary budget deficit-to-GDP ratio also shows similar or even worse results. Since 1997 Slovenia has been under the limit.

It is very likely that in near future public finance's situation in Slovenia could ceteris paribus - become relatively unfavorable or even unsustainable. Therefore a reform of public finances would be necessary; the reform should enforce adjustment of the actual budget deficit to the limit, calculated by or similar proposed methodology. Something could be done also with promotion of high economic growth and low costs of public debt; the later could be achieved with a more active debt mana- 
gement. Although current costs of state borrowing is relatively low (with respect to benchmark), past borrowing was fairly costly. Therefore it would be necessary to reconstruct the public debt and so lower its actual costs.

\section{References}

Blanchard, O., Jean-Claude, Ch., Hagemann, R. P., Sartor, N. (1990), "The Sustainability of Fiscal Policy: New Answers to an Old Question". OECD Economic Studies No. 15. Paris: Organisation for Economic Co-operation and Development.

Collignon, S., Mundschenk, S. (1999), The Sustainability of Public Debt in Europe. Economia Internazionale 1, pp. 101-159.

Commission of European Communities (1992), Treaty on European Union. Luxemburg: Office for Official Publications of the European Communities.

De Haan, J. C., Sierman, L. J. (1993), The Intertemporal Government Budget Constraint: an Application for the Netherlands. Public Finance, 48 (2), pp. 243-249.

Easterly, W., Rodriguez, C. A., Schmidt-Hebbel, K. (1995), Public Sector Deficits and Macroeconomics Performance. Washington D. C.: The World Bank.

ECB (2004), Monthly Bulletin, January. Frankfurt: European Central Bank.

Eichengreen, B., Wyplosz, Ch. (1998), The Stability Pact: More than a Minor Nuisance? Economic Policy, 1 (26), pp. 65-119.

Fatás, A., Mihov, I. (2003), On Constraining Fiscal Policy Discretion in EMU. Oxford Review of Economic Policy, 19 (1), pp. 112-131.

Ferligoj, A. (1989), "Razvrščanje v skupine. Teorija in uporaba v družboslovju". Metodološki zvezki št. 4. Ljubljana: Fakulteta za sociologijo, politične vede in novinarstvo.

Heinemann, F. (1993), The Sustainability of National Debt in Europe. Intereconomics 28 (2), pp. 61-68.

Herring, B. (1995), The Sustainability of Budget Deficits in a Stohastic Economy. Journal of Money, Credit and Banking, 27 (1), pp. 257-271.

Mac Donald, R., Speight, A. E. H. (1990), The Intertemporal Budget Constraint in the UK, 19611986. The Manchaster School, 63 (4), pp. 329-347.

McCallum, B. T. (1984), Are Bond-Financed Deficits inflationary? A Ricardian Analysis. Journal of Political Economy 92 (2), pp. 123-135.

Ministrstvo za finance (2005), Bilten javnih financ, januar 2005. Ljubljana: Ministrstvo za finance.

OECD (2003), Economic Outlook, June 2003. Paris: Organisation for Economic Co-operation and Development.

Papadopoulos, A. P., Sidiropoulos, M. G. (1999), The Sustainability of Fiscal Policies in the European Union. International Advances in Economic Research, 5 (3), pp. 289-307.

Pasinetti, L. L. (1998), The Myth (of Folly) of the $3 \%$ Deficit/GDP Maastricht 'Parameter'. Cambridge Journal of Economics, 22 (1), pp. 103-116.

Uctum, M., Wickens, M. (1997), "Debt and Deficit Ceilings, and Sustainability of Fiscal Policies: an Intertemporal Analysis". CEPR Discussion Papers No. 1612. London: Centre for Economic Policy Research.

UMAR (1996), Ekonomsko ogledalo, december 1996. Ljubljana: Urad za makroekonomske analize in razvoj.

(2005), Ekonomsko ogledalo, januar 2005. Ljubljana: Urad za makroekonomske analize in razvoj. 